\section{JURNAL ABDIMAS

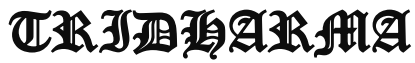

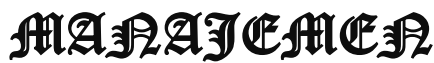

ISSN 2615-6849, E-ISSN 2716-070X

rnal ABDIMAS Vol.3,No.1,Desember 2021,Hal(72-78)

?rodi Manajemen Fakultas Ekonomi Universitas Pamulang Iail: abdimasjurnal.unpam@gmail.com Telp: (021) 741-2566

\title{
FUN LEARNING AND GAME SEBAGAI MEDIA PEMBELAJARAN BAHASA INGGRIS UNTUK ANAK
}

\author{
Yenni Cahyani ${ }^{1}$ Rachma Wati $^{2}$, Sri Agustina ${ }^{3}$, Diah Mardiani ${ }^{4}$, Nur Anissa ${ }^{5}$ \\ ${ }^{1}$ Dosen Prodi Akuntansi Fakultas Ekonomi dan Bisnis Universitas Pamulang \\ ${ }^{2,3,4,5}$ Mahasiswa Akuntnasi Universitas Pamulang \\ Email : dosen02195@unpam.ac.id, rachmawati020899@gmail.com, tinaaquarius02@gmail.com, \\ diahmardiani98@gmail.com, anissaica99@gmail.com
}

\begin{abstract}
ABSTRAK
Abstrak: Kegiatan Pengabdian ini merupakan kegiatan pengabdian yang melibatkan mahasiswa program studi akuntnasi Universitas Pamulang. Sebanyak satu dosen pembimbing dan 4 orang mahasiswa turut serta dalam pelaksanaan pengabdian ini. Mahasiswa tersebut merupakan mahasiswa semester 8. Dalam kegiatan ini dosen prodi akuntansi berperan dalam membimbing mahasiswa mempersiapkan kegiatan belajar mengajar terhadap anak-anak di Taman Baca Buaran Hijau. Dengan mempertimbangkan aspek dalam pengajaran, mahasiswa dipersiapkan untuk memberikan kegiatan-kegiatan yang tepat dan bermakna untuk meningkatkan motivasi dan keterampilan Berbahasa Inggris pada anak. Hasil kegiatan pengabdian ini memberikan hasil yang positif bagi anak-anak di Taman Baca Buaran Hijau dalam belajar Bahasa Inggris yang menyenangkan dengan metode pembelajar secara tatap muka dengan pemberian materi dengan flascard beserta permainan game question tentang materi yang diajarkan dan pemberian hadiah bagi yang dapat menjawab pertanyaan game dengan benar.
\end{abstract}

Keywords: Pembelajaran bahasa inggris, metode flascard, Motivasi anak, Game

Abstract: This service activity is a service activity that involves students of the Pamulang University accounting study program. A total of one lecturer and 4 students participated in the implementation of this service. The student is an 8th semester student. In this activity, the accounting study program lecturer plays a role in guiding students to prepare teaching and learning activities for children at Taman Baca Buaran Hijau. By considering aspects of teaching, students are prepared to provide appropriate and meaningful activities to increase motivation and English language skills in children. The results of this service activity gave positive results for children at Taman Baca Buaran Hijau in learning English in a fun way with the face-to-face learning method by providing material with flashcards along with game questions about the material being taught and giving prizes for those who can answer game questions. correctly.

Keywords: English learning, flashcard method, children's motivation, Game

\section{PENDAHULUAN}

Di era zaman yang semakin terus maju tidak dapat dipungkiri bahwa kebutuhan akan keterampilan Berbahasa Inggris terus meningkat. Bahkan sudah banyak diusia dini yang sudah menggunakan Bahasa Inggris dalam kehidupan sehari-harinya. Menurut Ningsih dan Rahmawati (2018) mereka akan sangat ketinggalan informasi apabila tidak menguasai atau mengerti Bahasa Inggris. Pembelajaran Bahasa Inggris saat ini 


\section{JURNAL ABDIMAS

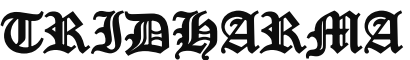 AtA}

ISSN 2615-6849, E-ISSN 2716-070X

rnal ABDIMAS Vol.3,No.1,Desember 2021,Hal(72-78)

गrodi Manajemen Fakultas Ekonomi Universitas Pamulang

aail: abdimasjurnal.unpam@ gmail.com Telp: (021) 741-2566 lebih mudah karena banyak buku dan peralatan yang menggunakan instruksi Bahasa Inggris.

Menurut Kamlis (2019) pada zaman dahulu Bahasa Inggris dianggap sebagai mata pelajaran yang sulit dan menakutkan, tetapi seiring dengan perkembangan ilmu pengetahuan dan tekhnologi yang menuntut untuk menguasai Bahasa Inggris. Saat ini, Bahasa Inggris tidak dianggap sesuatu yang asing bagi siswa. Melalui kegiatan pengabdian ini, mahasiswa dibimbing untuk melaksanakan pembelajaran bahasa inggris dalam bentuk tatap muka langsung. Anak- anak di Taman Baca Buaran Hijau menjadi subjek dalam pengajaran ini. Anak-anak yang mengikuti kegiatan ini juga diharapkan dapat mengenal proses pembelajaran Bahasa Inggris yang diharapakan menyenangkan dan dapat menjadi bekal yang bermanfaat bagi ketrampilan berbahasa mereka.

Adapupun rumusan masalah pada kegiatan pengabdian ini tertuang dalam beberapa perntanyaan;

1. Apakah kegiatan pengabdian ini dapat memotivasi anak-anak di taman baca buaran dalam belajar Bahasa Inggris?

2. Apakah kegiatan pengabdian ini dapat memberikan pengalaman belajar bahasa inggris yang menyenangkan dan komunikatif bagi anakanak di Taman Baca Buaran Hijau?

\section{KAJIAN TEORI}

\subsection{Metode pengajaran dengan menggunakan flashcard}

Pembelajaran Bahasa Inggris tidak hanya dipelajari mulai dari tingkat sekolah dasar saja. Pada saat ini pembelajaran bahasa Inggris sudah dimulai sejak Taman Kanak-kanak. Pembelajaran yang dimulai dengan mengenalkan kosakata Bahasa Inggris terhadap siswa-siswi nya merupakan salah satu tujuan dari sekolah ini agar tidak ketinggalan di era globalisasi yang semakin maju ini. Media flashcard adalah kartu yang digunakan untuk mengingat dan mengkaji ulang dalam proses belajar. Pada kesempatan kali ini tim pengabdian kepada masyarakat memberikan pelatihan penggunaan media flashcard sebagai media pembelajaran kosakata bahasa Inggris. Tujuannya adalah melatih otak kanan untuk mengingat gambar dan kata, sehingga dapat menambah jumlah perbendaharaan kosakata.

\subsection{Penelitian Yang Terkait}

Kegiatan PKM ini untuk memberikan wawasan tentang belajar inggris yang memotivasi dan menarik agar anak-anak diusia dini dapat mengenal bahasa inggris. Ada beberapa penelitian lain terkait penelitian ini : Ginting dkk (2018), melakukan penelitian dengan judul Pelatihan Kosa Kata Bahasa Inggris Menggunakan Media Gambar Untuk Anak-Anak Desa Jaring Halus, Kec. Secanggang,Kab. Langkat. Hasil pelatihan menunjukkan bahwa sepuluh anak memiliki kemampuan rendah setelah mengikuti kegiatan pelatihan kosa-kata Bahasa Inggris. Sementara itu, lima anak memiliki kemampuan menengah setelah mengikuti kegiatan Bahasa inggris. Ningsih dan Rahmawati (2018) melakukan penelitian dengan judul Pembelajaran Bahasa Inggris Untuk Para Siswa Sekolah Dasar Di Rumah Belajar Sosial. Hasil kegiatan adalah: di rumah belajar Sido Rahayu: $100 \%$ dari 13 siswa selalumengikuti kegiatan 2 kali seminggu.90\% siswa memahami materi dan dapat mengerjakan soal yang diberikan secara tertulis. $80 \%$ siswa dapat mengerjakan secara mandiri soal yang diberikan guru di sekolah dan bisa melakukan percakapan. Di rumah belajar Pandan Landung: 100\% dari 11 siswa aktifmengikuti kegiatan. $75 \%$ siswamemahami materi dan dapat mengerjakan soal tertulis. $60 \%$ siswa dapat mengerjakan secara mandiri soal yang diberikan guru di sekolah dan melakukan percakapan sederhana. Ningsih (2021) melakukan penelitian dengan judul Media Flashcard Dalam Pengajaran Kosakata Bahasa Inggris. Berdasarkan dari kegiatan pengabdian yang telah dilakukan di TK Kemala Bhayangkari 03 Medan maka dapat disimpulkan penggunaan media pembelajaran sangat penting dalam mengajarkan kosakata Bahasa Inggris. Media flashcard dapat meningkatkan atau menambah perbendaharaan kosakata siswa-siswi TK Kemala Bhayangkari 03 Medan. 


\section{JURNAL ABDIMAS

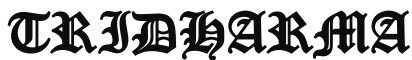

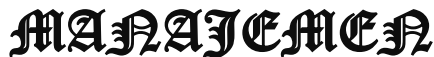

ISSN 2615-6849, E-ISSN 2716-070X

rnal ABDIMAS Vol.3,No.1,Desember 2021,Hal(72-78)

?rodi Manajemen Fakultas Ekonomi Universitas Pamulang aail: abdimasjurnal.unpam@ gmail.com Telp: (021) 741-2566

\section{METODE PENGABDIAN}

\subsection{Lokasi Pengabdian}

Program Pengabdian kepada Masyarakat yang dilaksanakan secara tatap muka berkalborasi dengan dosen pembimbing Prodi Akuntansi UNPAM, kegiatan ini dilaksanakan di Taman Baca Buaran Hijau bertempat di Jl. Masjid Buaran Serpong- Tangerang Selatan.

\subsection{Metode Pengabdian}

Menurut Rahmadhani (2021) metode dalam pelaksanaan yaitu peserta latih dan bentuk kegiatan dengan memberikan game kepada anakanak. Metode yang digunakan dalam pengabdian ini yaitu untuk anak-anak di Taman baca Buaran Hijau adalah sebagai berikut:

1. Pemberian materi

Materi yang dimaksud adalah Pemaparan materi kegiatan berupa materi terkait kosa kata, nama warna, nama-nama angka 1-20 dan nama-nama bentuk dalam bentuk gambar dalam bahasa inggris.

\section{Game}

Game yang dimaksud adalah setelah memberikan materi yang diajarkan, kami memberikan question tentang materi yang sudah diajarkan sehingga yang dapat menjawab dengan benar akan mendapatkan hadiah berupa botol minum yang sudah dikemas dalam bentuk hadiah.

\subsubsection{Analisa Situasi Lapangan}

Berdasarkan pengalaman PKM yang dilakukan oleh dosen dan mahasiwa Prodi Akuntnasi tahun 2021 berupa pengajaran dan bakti sosial, akhirnya kami putuskan untuk mengambil Taman Baca Buaran sebagai setting program pengabdian kepada masyarakat.

\subsubsection{Identifikasi Masalah}

Kami menghubungi pihak pengurus

Taman Baca Buaran untuk kemungkinan bisa melakukan program PKM. Selanjutnya, kami datang ke Taman Baca Buaran untuk survei dan sedikit berbincang dengan pengurus Taman Baca Buaran untuk mendapatkan informasi lebih detail dan terkini menggenai kondisi dan juga peserta anak-anak yang akan mengikuti pembelajaran mengenai bahasa inggris. Hasilnya, kami dapat mengidentifikasi masalah bahwasannya pembelajaran Bahasa Inggris di Taman Baca Buaran kurang efektif dimana anak-anak mayoritas menganggap Bahasa Inggris sebagai Bahasa asing yang susah dipelajari.

\subsubsection{Menentukan Tujuan Kerja secara Spesifik}

Dengan mempertimbangkan banyak aspek, akhirnya kami putuskan bahwa tujuan dari PKM ini ialah untuk memberikan motivasi pembelajaran Bahasa Inggris kepada anak-anak di Taman Baca Buaran supaya mereka mendapatkan pengalaman bahwa belajar Bahasa Inggris itu menyenangkan dan mudah. Tujuan akhirnya diharapkan mereka dapat termotivasi untuk mempelajari Bahasa Inggris.

\subsubsection{Rencana Pemecahan Masalah}

Setelah melalui tahap penetuan tujuan, tim PKM Prodi Akuntansi Universitas Pamulang melakukan beberapa tahapan kegiatan untuk memecahkan masalah:

1) Mencari alternative 'strategi' atau 'tehnik' menggajar seperti apa yang cocok untuk anakanak di Taman Baca Buaran

2) Memilih dari beberapa alternative tersebut, yang pada akhirnya kami putuskan untuk menggunakan games dalam bentuk question dari materi yang diajarakan dan memberikan hadiah jika yang dapat menjawab dengan benar.

\subsubsection{Pelaksanaan Kegiatan}

Dalam pelaksanaan kegiatan ini Team PKM datang secara langsung pada lokasi PKM dilaksanakan pada Taman Baca Buaran. Program PKM ini melibatkan dosen dan mahasiswa Fakultas Akuntansi Universitas Pamulang. Mahasiswa yang terlibat pada kegiatan ini merupakan mahasiswa yang mengambil mata kuliah jurusan akuntansi dengan jumlah 4 orang. Hal tersebut sejalan dengan tujuan program PKM yang dilaksanakan yaitu memberikan motivasi pembelajaran Bahasa Inggris yang menyenangkan kepada anak-anak di Taman Baca 


\section{JURNAL ABDIMAS

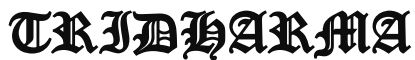

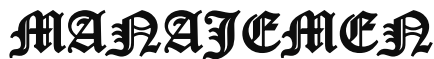

ISSN 2615-6849, E-ISSN 2716-070X

rnal ABDIMAS Vol.3,No.1,Desember 2021,Hal(72-78)

गrodi Manajemen Fakultas Ekonomi Universitas Pamulang

aail: abdimasjurnal.unpam@gmail.com Telp: (021) 741-2566
Buaran Hijau. Terdapat 16 anak yang ikut berpartisipasi dalam PKM ini.

\subsubsection{Evaluasi Kegiatan dan Hasil}

Sebagai bentuk pertanggungjawaban tim PKM Prodi Akuntansi atas setiap tahapan yang dilalui sampai dengan pelaksanaan riil di lapangan, kami menggadakan pertemuan antara dosen dan mahasiswa untuk merefleksi apa yang sudah dilakukan. Informasi penting menggenai: hal apa yang harus dibenahi selama persiapan-pelaksanaan PKM, komentar/saran/kritik apa dari anak-anak, maupun penggurus Taman Baca Buaran Hijau yang mungkin disampaikan ke mahasiswa atau dosen secara personal pasca pelaksanaan, dibahas dalam pertemuan tersebut.

\section{PEMBAHASAN DAN HASIL}

\section{KEGIATAN}

\subsection{Pelaksanaan Program}

Program Pengabdian Kepada Masyarakat yang dilakasanakan pada Taman Baca Buaran Hijau melibatkan dosen pembimbing dan sekelompok mahasiswa yang terdiri dari 4 anggota.

\subsection{Hasil Program}

Program PKM yang dilaksanakan pada anak-anak di Taman Baca Buaran Hijau yang di hadiri 16 anak memberikan hasil yang positif yang dapat dirasakan tidak hanya oleh anak-anak tetapi juga dosen dan mahasiswa yang terlibat. Bagi anak-anak pada Taman Baca Buaran Hijau, program ini memberikan kesempatan untuk dapat berlatih menggunakan Bahasa Inggris diluar jam sekolah.

Hasil kegiatan pengabdian ini memberikan hasil yang positif bagi anak-anak di Taman Baca Buaran Hijau dalam belajar Bahasa Inggris yang menyenangkan dengan metode pembelajar secara tatap muka dengan pemberian materi dengan flascard beserta permainan game question tentang materi yang diajarkan dan pemberian hadiah bagi yang dapat menjawab pertanyaan game dengan benar. Hasil kegiatan PKM ini dapat dilihat dari keaktifan anak-anak dalam mengikuti pembelajaran bahasa inggris sebagai berikut :

\section{Tabel 4.1 Hasil dari Kegiatan PKM}

\begin{tabular}{|c|c|c|c|c|}
\hline No & Nama & Materi & Game Question & Hasil \\
\hline 1 & Intan & Aktif & Aktif & Positif \\
\hline 2 & Putri & Aktif & Aktif & Positif \\
\hline 3 & Tania & Aktif & Aktif & Positif \\
\hline 4 & Andin & Aktif & Aktif & Positif \\
\hline 5 & Ica & Aktif & Aktif & Positif \\
\hline 6 & Hana & Aktif & Aktif & Positif \\
\hline 7 & Sasa & Aktif & Aktif & Positif \\
\hline 8 & Khalifa & Aktif & Aktif & Positif \\
\hline 9 & Elisa & Aktif & Aktif & Positif \\
\hline 10 & Nur Aini & Aktif & Aktif & Positif \\
\hline 11 & Rika & Aktif & Aktif & Positif \\
\hline 12 & Ririn & Aktif & Aktif & Positif \\
\hline 13 & Siti & Aktif & Aktif & Positif \\
\hline 14 & Kartika & Aktif & Aktif & Positif \\
\hline 15 & Cindi & Aktif & Aktif & Positif \\
\hline 16 & Talia & Aktif & Aktif & Positif \\
\hline
\end{tabular}

\section{PENUTUP}

\subsection{Kesimpulan}

Program PKM berupa pembelajaran Bahasa Inggris bagi anak-anak di Taman Baca Buaran merupakan kegiatan yang memberikan dampak positif bagi pihak - pihak yang terlibat. Program ini telah memberikan motivasi pada pembelajaran Bahasa Inggris yang dianggap cukup sulit bagi anak-anak.

\subsection{Saran}

Pelaksanaan program PKM pada Taman Baca Buaran diharapkan dapat berlanjut dan menjadi kegiatan rutin. suasana belajar yang menyenagkan akan membuat anak-anak betah, nyaman dan semakin haus untuk belajar. Dengan kondisi ini, berarti anak-anak akan berkeinginan untuk belajar tanpa paksaan dari siapa pun.

\section{DAFTAR PUSTAKA}

As'ari, C., Iswadi, \& Afrizal, M. (2021). "Pengajaran Bahasa Inggris Terhadap Siswa Tingkat Dasar Di Rumah Qur'an Khairul Ummah Kecamatan Gandapura. Jurnal Pengabdian Kepada Masyarakat Vol. 4, No. 2, 84 - 90. 


\section{JURNAL ABDIMAS

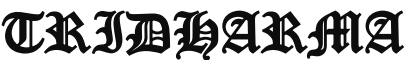

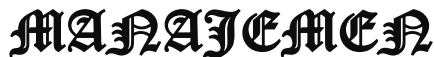

ISSN 2615-6849, E-ISSN 2716-070X

rnal ABDIMAS Vol.3,No.1,Desember 2021,Hal(72-78)

?rodi Manajemen Fakultas Ekonomi Universitas Pamulang

aail: abdimasjurnal.unpam@ gmail.com Telp: (021) 741-2566
Budianto, S. (2019). Pengabdian Pada Masyarakat Pengajaran Kosakata Bahasa Inggris Untuk Anak Melalui Media Gambar Dan Bermain Di Dolly English Club. Jurnal Ilmiah Edukasi \& Sosial Volume 10, Nomor 2, , 165-168.

Ginting, D. A., Hassan, M., Lestari, N. S., Rahmadhani, M., Rosmen, Supriadi, Et Al. (2018). Pelatihan Kosa Kata Bahasa Inggris Menggunakan Media Gambar Untuk Anak-Anak Desa Jaring Halus, Kec. Secanggang, Kab. Langkat. Jurnal Pengabdian Kepada Masyarakat (Jpkm) Vol 1, No.1, 13-21.

Hastuti, N., \& Roviati, E. (2020). Pendampingan Belajar Pengenalan Bahasa Inggris Menyenangkan Dari Rumah Di Masa Pandemi Covid 19. Jurnal Ilmiah Pengabdian Kepada Masyarakat Vol.3 No. 2.

Kamlasi, I. (2019). Bimbingan Belajar Bahasa Inggris Bagi Anak-Anak Sekolah Dasar . Jurnal Abdimas Bsi Vol. 2 No. 1, 260267.

Muliyah, P., \& Fernando, F. (2018). Pelatihan Pengenalan Bahasa Inggris Untuk Anak Usia Dini Melalui Igra. Dedikasi: Jurnal Pengabdian Masyarakat Vol. 1 No. 1 , 20-36.

Ningsih, A. M. (2021). Media Flashcard Dalam Pengajaran Kosakata Bahasa Inggris. Journal Of Social Responsibility Projects By Higher Education Forum Vol 2, No 1, 1-3.

Ningsih, M. S., \& Rahmawati, N. M. (2018). Pembelajaran Bahasa Inggris Untuk Para Siswa Sekolah Dasar Di Rumah Belajar Sosial. Jpm (Jurnal Pemberdayaan Masyarakat) Vol. 3 No. 1, 205-212.

Pasaribu, V. L. D., Agrasadya, A., Shabrina, N., \& Krisnaldy, K. (2020). Menjadi Enterpreneur Muda Yang Memiliki Jiwa Leadership Untuk Menghadapi Masa Depan. Abdi Laksana: Jurnal Pengabdian Kepada Masyarakat, 1(1).

Pasaribu, V. L. D., Susanti, F., \& Hartuti, E. T. K. (2019). Memotivasi Siswa dan Siswi
SMK Letris Indonesia di Dalam Menentukan Pilihan Untuk Melanjutkan Pendidikan Atau Bekerja Setelah Lulus Sekolah. Jurnal Pengabdian Dharma Laksana, 1(2), 161-172.

Pasaribu, V. L. D., Sulaiman, S., Sutiman, S., Thaharudin, T., \& Purnomo, B. Y. (2020). Pengenalan Letak Posyandu Terdekat Dikelurahan Pisangan Dengan Manajemen Pemasaran Revolusi 4.0 Untuk Meningkatkan Pengetahuan Masyarakat Letak Dan Fungsi Posyandu Terdekat Pada Kelurahan Pisangan. Dedikasi Pkm, 1(1), 105-110.

Pasaribu, V. L. D., Oktrima, B., Prabowo, B., Arianto, N., \& Haryoko, U. B. (2020). Progam Pendampingan Dan Penyelenggaraan Pendidikan Anak Pada Usia Dini Terhadap Prestasi Belajar Dilingkungan Rt 020 Rw 009. Kel Giri Peni. Kec Wates. Yogyakarta. Jurnal Lokabmas Kreatif, 1(1), 71-75.

Pasaribu, V. L. D., Jannah, M., Fazar, M., Putra, S. P., Monalisa, M., \& Sofa, M. (2021). MENINGKATKAN

PRODUKTIVITAS USAHA DIMASA PANDEMI PADA IBU PKK RT 004/003 KELURAHAN SAWAH BARU CIPUTAT, TANGERANG SELATAN. Abdi Laksana: Jurnal Pengabdian Kepada Masyarakat, 2(2), 295-301.

Pasaribu, V. L. D., Yuniati, H. L., Pranata, R., Sembayu, R., Purba, S. M., \& Nurbayani, T. T. A. (2021). MANAJEMEN KEUANGAN UNTUK MENGHADAPI DAN BERTAHAN DI ERA COVID 19. Jurnal Abdimas Tri Dharma Manajemen, 2(2), 12-18.

Pasaribu, V. L. D., Dwiyatni, A., Sabina, C., Ridwan, M., Gunawan, D. D., \& Noviani, B. C. (2021). EVALUASI PENERAPAN 3M DIMASA PANDEMIC COVID 19. Jurnal Abdimas Tri Dharma Manajemen, 2(2), 54-60.

Pasaribu, V. L. D., Syafei, A. N., Farhan, A., 


\section{JURNAL ABDIMAS

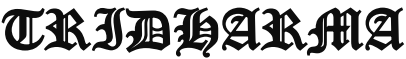

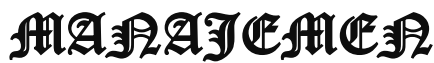

ISSN 2615-6849, E-ISSN 2716-070X

rnal ABDIMAS Vol.3,No.1,Desember 2021,Hal(72-78)

गrodi Manajemen Fakultas Ekonomi Universitas Pamulang

aail: abdimasjurnal.unpam@ gmail.com Telp: (021) 741-2566
Aufaizah, A., Irani, C., \& Firtiayani, S.

R. (2021). PENGARUH DISPLIN

PROTOKOL

KESEHATAN

TERHADAP

PENCEGAHAN

PENULARAN VIRUS COVID-

19. Jurnal Abdimas Tri Dharma Manajemen, 2(2), 91-98.

Pasaribu, V. L. D., Septiani, F., Rahayu, S., Lismiatun, L., Arief, M., Juanda, A., ... \& Rahim, R. (2021). Forecast Analysis of Gross Regional Domestic Product based on the Linear Regression Algorithm Technique.

Priadi, A., Pasaribu, V. L. D., Virby, S., Sairin, S., \& Wardani, W. G. (2020). Penguatan Ekonomi Kreatif Berbasis Sumber Daya Desa Dikelurahan Rempoa. Abdi Laksana: Jurnal Pengabdian Kepada Masyarakat, 1(3), 356-35

Pasaribu, V. L. D., Priadi, A., Anismadiyah, V., Rahayu, S., \& Maduningtias, L. (2021). PENYULUHAN KREATIF DAN INOVATIF MENINGKATKAN MUTU PRODUKSI UMKM DI DESA BELEGA KABUPATEN GIANYAR. Pro Bono Jurnal Pengabdian Kepada Masyarakat, 1(02).

\section{DOKUMENTASI FOTO KEGIATAN}

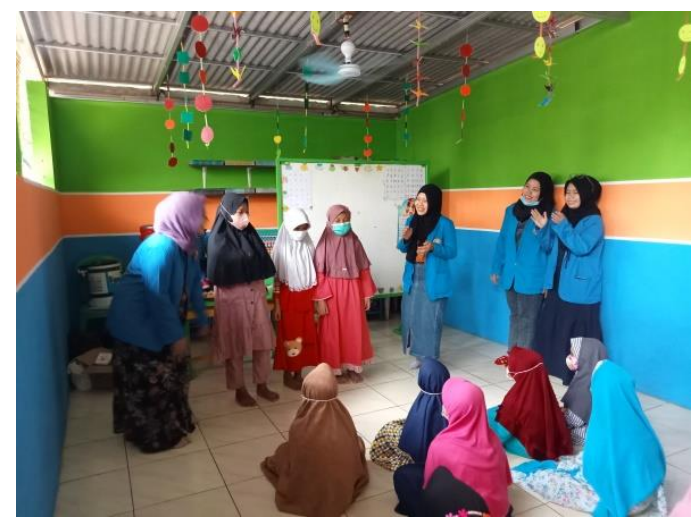

Pasaribu, V. L. D. (2021). PELATIHAN BERBASIS ONLINE DI ERA COVID19. Jurnal Abdimas Tri Dharma Manajemen, 2(3), 26-32.

Pasaribu, V. L. D., \& Setyowati, R. (2021). ADAPTASI KEHIDUPAN NEW NORMAL PADA MASA PANDEMI COVID-19 DIYAYASAN PONDOK PESANTREN DAN PANTI ASUHAN NURUL IKHSAN KECAMATAN SETU, KOTA TANGERANG SELATAN. Jurnal Lokabmas Kreatif: Loyalitas Kreatifitas Abdi Masyarakat Kreatif, 2(2), 82-88.

Rahmadhani, M., \& Lestari, N. S. (2021). Sharing For Caring: Bersama Berbagi Ilmu Dan Manfaat Dalam Pembelajaran Bahasa Inggris Melalui Games. Jurnal Pengabdian Kepada Masyarakat (Jpkm) Vol. 2, No., 41-51.

Riance, A. (2021). Pendampingan Belajar Bahasa Inggris Menarik Dan Creative Pada Masa Pandemi Covid 19 Di Slb Negeri Lubuklinggau. Lp3mkil Vol. 1 No. 1, 1-8.

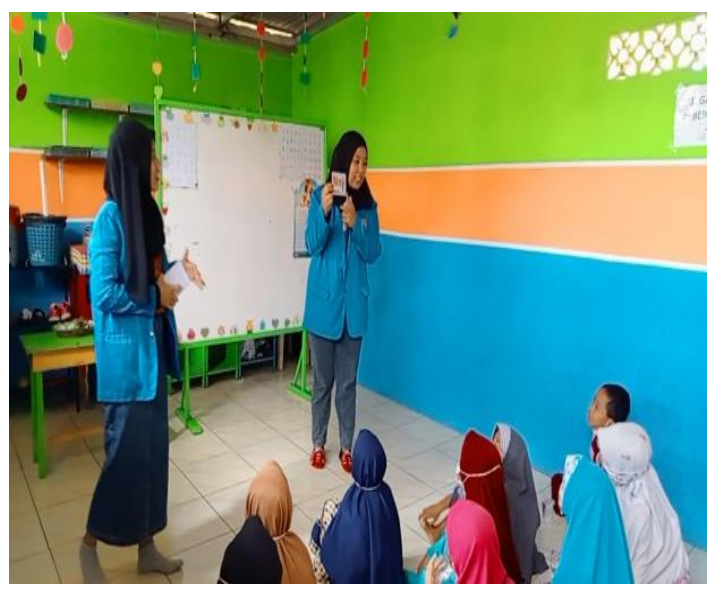




\begin{tabular}{|c|c|}
\hline JURNAL ABDIMAS & ISSN 2615-6849, E-ISSN 2716-070X \\
\hline 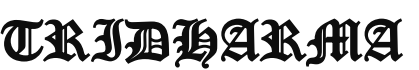 & rnal ABDIMAS Vol.3,No.1,Desember 2021,Hal(72-78) \\
\hline $18=\equiv 28$ & $\begin{array}{l}\text { rod1 Manajemen Fakultas Ekonomi Universitas Pamulang } \\
\text { lail: abdimasjurnal.unpam@ gmail.com Telp: (021) 741-2566 }\end{array}$ \\
\hline
\end{tabular}
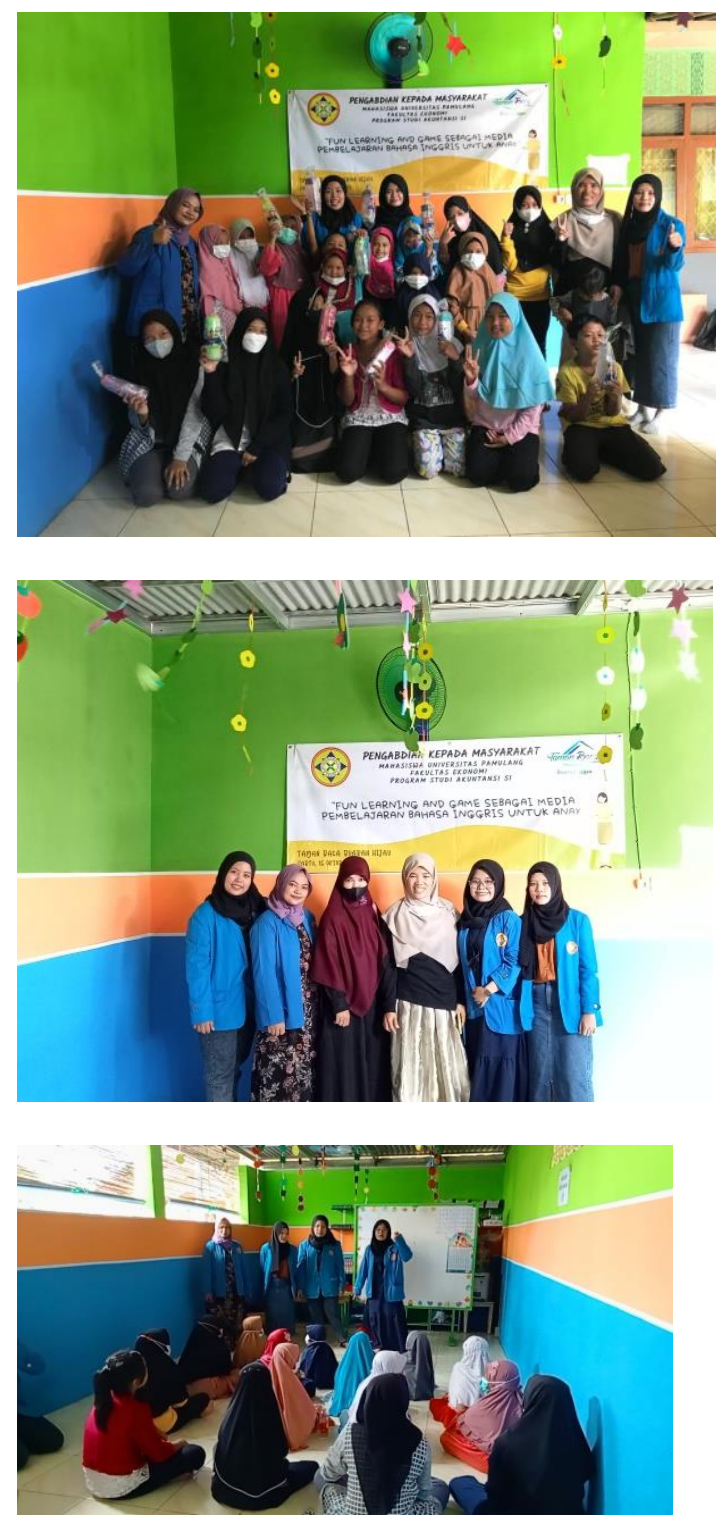